\title{
Staphylococcus lutrae sp. nov., a New Coagulase-Positive Species Isolated from Otters
}

\author{
G. FOSTER, ${ }^{1 *}$ H. M. ROSS, ${ }^{1}$ R. A. HUTSON,${ }^{2}$ AND M. D. COLLINS $^{2}$ \\ $S A C$ Veterinary Services, Drummondhill, Inverness IV2 4JZ, ${ }^{1}$ and BBSRC Institute \\ of Food Research, Reading RG6 $6 B Z{ }^{2}$ United Kingdom
}

\begin{abstract}
Phenotypic and phylogenetic studies were performed with three strains of a catalase-positive, gram-positive, coccus-shaped bacterium isolated from otters. The results of a 16S rRNA gene sequence analysis demonstrated that these strains represent a hitherto unknown subline within the genus Staphylococcus. Based on the results of the phylogenetic analysis and phenotypic criteria, we propose that these bacteria should be classified as members of a new species, Staphylococcus lutrae. The type strain of $S$. lutrae is DSM 10244.
\end{abstract}

Staphylococci are widespread in nature and are found consistently in association with mammals and birds (10). One species, Staphylococcus muscae, is associated with flies (6). Although the genus Staphylococcus currently comprises more than 30 species, it appears likely that many other species, particularly species from different animal hosts, await discovery. Staphylococci are routinely divided into two groups based on the results of the coagulase test (8). The coagulase-positive taxa Staphylococcus aureus, Staphylococcus intermedius, Staphylococcus delphini, and Staphylococcus schleiferi subsp. coagulans and the coagulase-variable species Staphylococcus hyicus are recognized as potentially serious pathogens.

In the course of bacteriological investigations of European otters (Lutra lutra) following postmortem examinations, a coagulase-positive Staphylococcus-like organism was isolated from three animals. We describe here the phenotypic and phylogenetic characterization of this Staphylococcus-like organism. Based on the taxonomic results presented below, a new species, Staphylococcus lutrae, is described.

\section{MATERIALS AND METHODS}

Isolation and cultivation. Three otter carcasses were found on different islands in the Inner Hebrides, which lie to the west of the Scottish mainland. The locations of the animals and the tissue sources of coagulase-positive staphylococci are shown in Table 1. The organisms were isolated on Columbia agar (Difco, East Molesey, United Kingdom) supplemented with 5\% citrated sheep blood (CSBA) that was incubated aerobically at $37^{\circ} \mathrm{C}$ for 18 to $24 \mathrm{~h}$. Subcultures on CSBA were used for characterization tests.

Biochemical characterization. Colonial morphology and pigmentation were observed on $\mathrm{P}$ agar (9) incubated for 3 days at $37^{\circ} \mathrm{C}$ and then for an additional 2 days at room temperature. Tolerance to $\mathrm{NaCl}$ was determined with $\mathrm{P}$ agar containing 10 and $15 \% \mathrm{NaCl}$. Catalase production was tested by placing a few drops of $3 \% \mathrm{H}_{2} \mathrm{O}_{2}$ onto colonies on tryptic soy agar (Difco) and observing the preparations for bubbles of oxygen. Oxidase activity was determined with $6 \%$ tetramethylphenylenediamine in dimethyl sulfoxide as described by Faller and Schleifer (4). Motility was determined with motility test medium (Difco). Clump-

TABLE 1. Sources of $S$. lutrae sp. nov, cultured from European otters (L. lutra)

\begin{tabular}{|c|c|c|c|}
\hline Strain & $\begin{array}{l}\text { Other } \\
\text { designation }\end{array}$ & Location & Tissue source \\
\hline M919/93/11 & DSM 10245 & Isle of Jura & Liver \\
\hline $\mathrm{M} 340 / 94 / 1^{\mathrm{T}}$ & DSM $10244^{\mathrm{T}}$ & Isle of Skye & $\begin{array}{l}\text { Mammary gland and supra- } \\
\text { mammary lymph node }\end{array}$ \\
\hline M2149/94/2 & DSM 10246 & Isle of Mull & Spleen \\
\hline
\end{tabular}

* Corresponding author. Mailing address: SAC Veterinary Services, Drummondhill, Stratherrick Road, Inverness IV2 4JZ, United Kingdom. ing factor and free coagulase activity were tested with coagulase plasma EDTA (Difco). DNase activity was determined by the method of Devriese and Van De Kerckhove (3). Briefly, cultures were inoculated as narrow streaks onto DNase agar (Oxoid, Basingstoke, United Kingdom) that was $4 \mathrm{~mm}$ deep, and the preparations were incubated at $37^{\circ} \mathrm{C}$ for $24 \mathrm{~h}$. After incubation, the cultures were flooded with $1 \mathrm{~N} \mathrm{HCl}$, and the diameters of growth streaks and clear reaction zones were measured. Reaction zones whose diameters were equal to or larger than four times the diameters of the growth streaks were considered positive. Reaction zones that were less than four times the diameters of the growth streaks were considered weakly positive. Hyaluronidase activity was determined by the method of Devriese et al. (2) by spreading a Pasteurella multocida capsular type A strain on the surface of a tryptic soy agar plate supplemented with $5 \%$ inactivated horse serum (Difco). Sample strains were spot inoculated. The appearance of zones of nonmucoid colonies surrounding the staphylococcal colonies indicated that hyaluronidase production occurred. Anaerobic growth was tested in Brewer thioglycolate medium (Difco). Susceptibility to lysostaphin was determined by flooding the surface of a $\mathrm{P}$ agar plate with $0.5 \mathrm{ml}$ of a bacterial suspension containing $10^{7}$ organisms per $\mathrm{ml}$ and allowing the preparation to dry before 1 drop of a $100-\mu \mathrm{g} / \mathrm{ml}$ solution of lysostaphin (Sigma Chemical Co., Poole, United Kingdom) was added. Susceptibility to $5 \mu \mathrm{g}$ of novobiocin, $250 \mu \mathrm{g}$ of deferoxamine, and $50 \mu \mathrm{g}$ of fosfomycin was determined on balanced sensitivity test medium (Difco) with Rosco tablets (Bioconnections, Leeds, United Kingdom). Arginine dihydrolase, prepared by the method of Møller (11), and urea broth (Oxoid) were inoculated and incubated at $37^{\circ} \mathrm{C}$ for $48 \mathrm{~h}$. The VogesProskauer reaction was determined with MRVP medium (Oxoid). Nitrate reduction was tested with Rosco tablets (Bioconnections). Acid production from carbohydrates was determined with $1 \%$ phenol red broth sugars prepared with phenol red broth base (Difco) and 1\% carbohydrate (Merck, Poole, United Kingdom). RAPIDEC Staph and API ZYM strips (BioMérieux, Basingstoke, United Kingdom) were also used with each strain according to the manufacturer's instructions. API ZYM reactions were scored as $0,1,2,3,4$, or 5 based on the color comparison chart of the manufacturer: Scores of 3 to 5 were considered strongly positive scores, and scores of 1 or 2 were considered weakly positive scores.

16S rRNA gene sequence analysis. A large fragment of the 16S rRNA gene was amplified from DNA by PCR with universal primers pA (positions 8 to 28 [Escherichia coli numbering]) and $\mathrm{pH}$ (positions 1542 to 1522). The amplified product was sequenced directly by using primers to conserved regions of the rRNA. Sequencing was performed with a PRISM DyeDeoxy terminator cycle sequencing kit (Applied Biosystems, Warrington, United Kingdom), and the reaction products were electrophoresed with an Applied Biosystems model 373A automatic DNA sequencer according to the manufacturer's protocols. Phylogenetic analyses were performed by using the Genetics Computer Group package

TABLE 2. Number of nucleotide differences between the $16 \mathrm{~S}$ rRNA of $S$. lutrae sp. nov. and the 16S rRNAs of closely related species

\begin{tabular}{lccccc}
\hline \multirow{2}{*}{ Species } & \multicolumn{5}{c}{ No. of nucleotide differences } \\
\cline { 2 - 6 } & S. lutrae & S. delphini & S. felis & S. intermedius & S. muscae \\
\hline S. delphini & 21 & & & & \\
S. felis & 22 & 26 & & & \\
S. intermedius & 15 & 9 & 24 & & 24 \\
S. muscae & 27 & 30 & 30 & 26 & \\
S. schleiferi & 22 & 17 & 24 & 12 & \\
\hline
\end{tabular}


TABLE 3. Characteristics which distinguish $S$. lutrae sp. nov. from other coagulase-positive Staphylococcus species and subspecies ${ }^{a}$

\begin{tabular}{|c|c|c|c|c|c|c|c|c|}
\hline Characteristic & S. lutrae & $\begin{array}{l}\text { S. schleiferi subsp. } \\
\text { coagulans }\end{array}$ & $\begin{array}{l}\text { S. schleiferi subsp. } \\
\text { schleiferi }\end{array}$ & $\begin{array}{l}S . \text { aureus subsp. } \\
\text { aureus }\end{array}$ & $\begin{array}{l}\text { S. aureus subsp. } \\
\text { anaerobius }\end{array}$ & S. intermedius & S. hyicus & S. delphini \\
\hline Aerobic growth & ${ }^{b}+$ & + & + & + & $-/ w$ & + & + & + \\
\hline Colony diam of $>5 \mathrm{~mm}$ & - & + & - & + & - & + & + & + \\
\hline Pigment & - & - & - & + & - & - & - & - \\
\hline Coagulase (rabbit plasma) & + & + & - & + & + & + & $\mathrm{d}$ & + \\
\hline Clumping factor & - & - & + & + & - & d & - & - \\
\hline DNase & + & + & + & + & + & + & + & - \\
\hline Hemolysis & + & + & + & + & + & + & - & + \\
\hline Acetoin production & - & + & + & + & - & - & - & - \\
\hline Hyaluronidase production & - & - & ND & + & + & - & + & ND \\
\hline \multicolumn{9}{|l|}{ Acid produced from: } \\
\hline Maltose & + & - & - & + & + & $-/ \mathrm{w}$ & - & + \\
\hline Galactose & + & + & ND & + & - & + & + & ND \\
\hline D-Trehalose & + & - & $\mathrm{d}$ & + & - & + & + & - \\
\hline D-Xylose & + & - & - & - & - & - & - & - \\
\hline
\end{tabular}

${ }^{a}$ Data from this study and reference 7 .

${ }^{b}+$, more than $90 \%$ of the strains are positive; - , more than $90 \%$ of the strains are negative; $\mathrm{d}, 11$ to $89 \%$ of the strains are positive; w, weak reaction; $-/ \mathrm{w}$, negative or weak reaction; ND, not determined.

(1) and the PHYLIP phylogeny inference package (5). Reference 16S rRNA sequences were retrieved from the EMBL and GenBank data libraries and were aligned with the newly determined sequence by using the program PILEUP (5). The rRNA alignment was corrected manually, and approximately 100 bases at the $5^{\prime}$ end of the molecule were omitted from further analyses because of alignment uncertainties. A distance matrix was calculated with the programs PRETTY (5) and DNADIST (1) by using the Kimura-2 parameter, and a phylogenetic tree based on the results of the neighbor-joining method was constructed by using the program NEIGHBOR (1). The stability of the groups was ascertained by performing a bootstrap analysis (200 replications) with the programs DNABOOT, DNADIST, NEIGHBOR, and CONSENSE (1).

Nucleotide sequence accession number. The 16S rRNA gene sequence of $S$. lutrae DSM $10244^{\mathrm{T}}$ has been deposited in EMBL Data Library under accession no. X84731.

\section{RESULTS AND DISCUSSION}

Three strains of gram-positive cocci that occur singly, in pairs, and in irregular clusters were isolated from dead otters. These three strains were phenotypically identical for the characteristics determined. Colonies on $\mathrm{P}$ agar were circular, entire, low convex, smooth, glistening, opaque, and nonpigmented with diameters of 3.5 to $4.5 \mathrm{~mm}$. On CSBA the colonies were 1.5 to $2.0 \mathrm{~mm}$ in diameter and produced hot and cold hemolysis after aerobic incubation at $37^{\circ} \mathrm{C}$ for $24 \mathrm{~h}$. Growth occurred at 25 and $42^{\circ} \mathrm{C}$ and in the presence of $10 \% \mathrm{NaCl}$ but

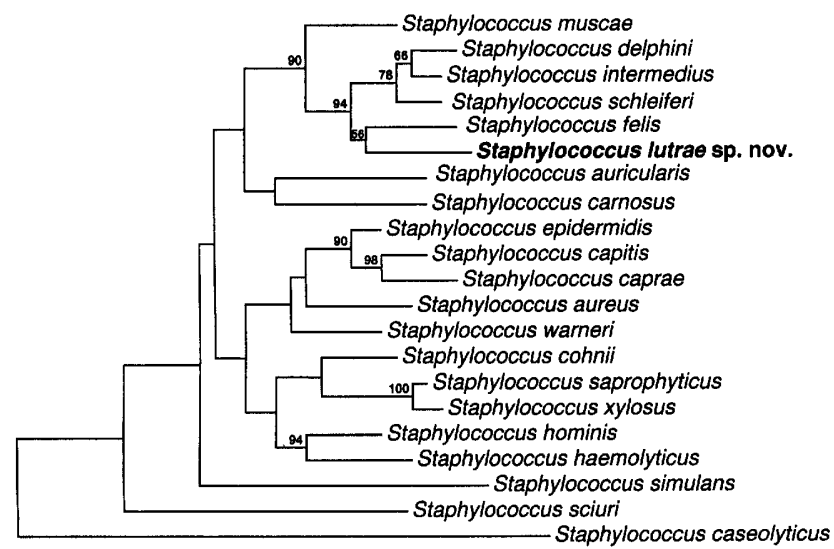

FIG. 1. Unrooted tree constructed by using the neighbor-joining method, showing the phylogenetic relationships of $S$. lutrae sp. nov. and other members of the genus Staphylococcus. not in the presence of $15 \% \mathrm{NaCl}$. Growth occurred in both the aerobic and anaerobic portions of thioglycolate medium. Cells were nonmotile, catalase positive, and oxidase negative. The tube coagulase test was positive, but clumping factor was not produced. DNase reactions were weakly positive, and hyaluronidase was not produced. Strains were sensitive to lysostaphin, novobiocin, fosfomycin, and deferoxamine. The arginine dihydrolase and Voges-Proskauer tests were negative. The urease test was positive, and nitrates were reduced. Acid was produced from adonitol, dulcitol, galactose, glucose, inositol, lactose, maltose, mannose, sorbitol, trehalose, and xylose. Two of the strains produced acid from mannitol. In the RAPIDEC Staph test, the organisms were negative for aurease and positive for alkaline phosphatase and $\beta$-galactosidase, which according to the manufacturer's instructions gave an identification of $S$. intermedius or Staphylococcus xylosus. In the API ZYM tests strong positive reactions were obtained for alkaline phosphatase, esterase, esterase-lipase, acid phosphatase, and naphthol-AS-BI-phosphohydrolase and weakly positive reactions were obtained for $\beta$-galactosidase and $\alpha$-fucosidase.

To establish the phylogenetic position of the unknown Staphylococcus species from otters, a large fragment $(>1,400$ nucleotides) of the $16 \mathrm{~S}$ rRNA gene from strain M340/94/1 ${ }^{\mathrm{T}}$ (= DSM $10244^{\mathrm{T}}$ ) was sequenced. Comparative sequence searches (data not shown) revealed that the unknown bacterium was indeed closely related to species of the genus Staphylococcus. Figure 1 is a tree which shows the phylogenetic relationships of the isolates from otters. From the phylogenetic analysis it is clear that the unidentified bacterium represents a new subline within the genus Staphylococcus. In particular, the otter bacterium exhibited a close phylogenetic association with $S$. delphini, Staphylococcus felis, S. intermedius, S. schleiferi, and S. muscae. Although a precise correlation between 16S rRNA sequence divergence and species differentiation is not possible, the numbers of nucleotide differences (Table 2) between the otter bacterium and its closest relatives are substantially higher than the observed numbers of differences between some Staphylococcus spp. known to be genotypically distinct as determined by DNA-DNA pairing. These considerations, together with the distinct subline formed by the otter bacterium and its distinctive phenotype, clearly indicate that this organism constitutes a hitherto unknown Staphylococcus sp. A new species, Staphylococcus lutrae, is proposed for the bacterium from otters. 
Description of Staphylococcus lutrae sp. nov. Staphylococcus lutrae (lu'trae. L. fem. gen. n. lutrae, of an otter). Cocci are arranged singly, in pairs, and in irregular clusters. Gram positive. Spores are not formed. Nonmotile. Colonies on P agar are circular, entire, low convex, smooth, glistening, opaque, nonpigmented, and 3.5 to $4.5 \mathrm{~mm}$ in diameter. Facultatively anaerobic. Hemolytic on sheep blood agar. Grows in the presence of $10 \%$ but not in the presence of $15 \% \mathrm{NaCl}$. Grows at 25 and $42^{\circ} \mathrm{C}$. Catalase positive and oxidase negative. Coagulase positive, but clumping factor is not produced. Weakly positive for DNase. Hyaluronidase is not produced. Nitrates are reduced. Arginine dihydrolase and Voges-Proskauer negative. Urease positive. Acid is produced from adonitol, dulcitol, galactose, glucose, inositol, lactose, maltose, mannose, sorbitol, trehalose, and xylose. Sensitive to novobiocin, deferoxamine, and fosfomycin. The $\mathrm{G}+\mathrm{C}$ content of the DNA is $34 \mathrm{~mol} \%$. Isolated from otters, for which it may be pathogenic. The type strain is DSM 10244. Characteristics useful for differentiating $S$. lutrae from the other coagulase-positive staphylococci are shown in Table 3.

\section{REFERENCES}

1. Devereux, J., P. Haeberli, and O. Smithies. 1984. A comprehensive set of sequence analysis programs for the VAX. Nucleic Acids Res. 12:387-395.

2. Devriese, L. A., B. Poutrel, R. Kilpper-Balz, and K. H. Schleifer. 1983.
Staphylococcus gallinarum and Staphylococcus caprae, two new species from animals. Int. J. Syst. Bacteriol. 33:480-486.

3. Devriese, L. A., and A. Van De Kerckhove. 1979. A comparison of methods and the validity of deoxyribonuclease tests for the characterization of staphylococci isolated from animals. J. Appl. Bacteriol. 46:385-393.

4. Faller, A., and K. H. Schleifer. 1981. Modified oxidase and benzidine tests for separation of staphylococci. J. Clin. Microbiol. 13:1031-1035.

5. Felsenstein, J. 1989. PHYLIP—phylogeny inference package (version 3.2). Cladistics 5:164-166.

6. Hajek, V., W. Ludwig, K. H. Schleifer, N. Springer, W. Zitzelsberger, R. M. Kroppenstedt, and M. Kocur. 1992. Staphylococcus muscae, a new species isolated from flies. Int. J. Syst. Bacteriol. 42:97-101.

7. Holt, J. G., N. R. Krieg, P. H. A. Sneath, J. T. Staley, and S. T. Williams. 1994. Bergey's manual of determinative bacteriology, 9th ed., p. 544-551. Williams and Wilkins, Baltimore, Md.

8. Kloos, W. E., and D. W. Lambe, Jr. 1991. Staphylococcus, p. 222-237. In A. Balows, W. J. Hausler, Jr., K. L. Herrmann, H. D. Isenberg, and H. J. Shadomy (ed.), Manual of clinical microbiology, 5th ed. American Society for Microbiology, Washington, D.C.

9. Kloos, W. E., T. G. Tornabene, and K. H. Schleifer. 1974. Isolation and characterization of micrococci from human skin, including two new species: Micrococcus lylae and Micrococcus kristinae. Int. J. Syst. Bacteriol. 24:79101.

10. Kloos, W. E., K. H. Schleifer, and F. Götz. 1992. The genus Staphylococcus, p. 1369-1420. In M. P. Starr, H. Stolp, H. G. Trüper, A. Balows, and H. G. Schlegel (ed.), The prokaryotes: a handbook on habitats, isolation and identification of bacteria. Springer-Verlag, New York, N.Y.

11. Møller, V. 1955. Simplified tests for some amino acid decarboxylases and for the arginine dihydrolase system. Acta Pathol. Microbiol. Scand. 36:158. 